\title{
Preference aktivního životního stylu v kontextu věku a míry ekonomického, sociálního a kulturního kapitálu ${ }^{1}$
}

\author{
Marcela Petrová Kafková ${ }^{2}$ \\ Ústav populačních studií, Fakulta sociálních studií, Masarykova univerzita, \\ Brno, Česká republika

\begin{abstract}
Preferences of Active Lifestyle in the Context of Age, Economic, Social and Cultural Capital. Activity is currently an integral part of the ageing concepts and is becoming more of a normative pressure to select and perform "appropriate" activities in old age. Therefore, the paper focuses on the determinants of the active lifestyle and their change with age. It confirms the influence of age and health on the inclination towards a more passive way of life and the limitation of the number of activities with age. However, there is also a strong conditionality by cultural, economic and social capital. People with higher levels of capitals have a more pro-active lifestyle and fulfil a wider range of activities. There is also a certain tension between the preference of active lifestyle in old age and the lower level of actual fulfilment in older age.

Sociológia 2019, Vol. 51 (No. 2: 198-218)

https://doi.org/10.31577/sociologia.2019.51.2.10
\end{abstract}

Key words: Ageing; active ageing; activities; older people; hobbies; life-style; Czech Republic

\section{Úvod}

Aktivita ve smyslu činorodosti je v současnosti se stárnutím pevně a zdá se, že neoddělitelně, spojena. Důležitost aktivity pro zachování fyzické i mentální svěžesti zmiňují už starověcí učenci, od přibližně 50. let dvacátého století pak gerontologové kladou stále větší důraz na aktivitu, jako nezbytný zdroj vyrovnání se se stárím. Podnětem pro tento příklon k aktivitě byly množící se lékařské a psychologické výzkumy dokazující význam aktivity pro zachování fyzické a mentální svěžesti do vyššího věku. Tento příklon k aktivitě vyústil ve formulaci teorie aktivity (activity theory) (Havighurst - Albrecht 1953) založené na přesvědčení, že starší lidé mají stejné psychické a sociální potřeby jako lidé středního věku. Teorie aktivity spojila aktivitu s životní spokojeností a kvalitou života. A z tohoto přesvědčení vycházejí všechny další teorie i koncepty stárnutí. Aktivita má pak i výrazně pozitivní vliv na stárnoucí (Silverstein - Parker 2002), jejich větší životní spokojenost (Marsillas et al. 2017; Menec - Chipperfield 1997) a snižuje riziko kognitivního postižení. (Fabrigoule et al. 1995) Navíc Havighurst a Albrecht označovali jimi prosazovanou podobu stárnutí jako úspěšné stárnutí (successful ageing) a toto spojení aktivity s „dobrým“

\footnotetext{
1 Tento článek vznikl s podporou projektu „Čtvrtý věk: identita disability v době aktivního stárnuti““ (GA15-03156S).

2 Korespondence: Mgr. Marcela Petrová Kafková, Ph.D., Ústav populačních studií, Fakulta sociálních studií, Masarykova univerzita, Joštova 10, Brno 602 00, Česká republika. E-mail: kafkova@fss.muni.cz
} 
stárnutím a pasivity $\mathrm{s}$ „neúspěšným“ stárnutím zůstává dosud velmi silné a produkuje nezanedbatelné nezamýšlené důsledky.

Jakýmsi zvýznamněním aktivity v současnosti je vítězství konceptu aktivního stárnutí (WHO 2002) v odborném i veřejném diskurz. (Hasmanová Marhánková 2014; Petrová Kafková 2013) Aktivní stárnutí tak, jak jej definuje Světová zdravotnická organizace (WHO 2002), se snaží být maximálně inkluzivním konceptem, proto je jeho definice značně obecná a rozpoznává značné množství determinant. A jde o koncepci celoživotní, tak jako stárnutí je proces, který nás provází od narození. Determinanty zahrnují materiální podmínky, sociální, environmentální faktory, stejně jako behaviorální a osobnostní determinanty a $\mathrm{v}$ neposlední řadě faktory strukturální. Všechny tyto faktory a jejich vzájemné vztahy mají ovlivňovat podobu stárnutí a kvalitu života ve stáŕí. Tyto determinanty jsou platné universálně v průběhu života, ne jen ve stáŕí. Nejen ve veřejném, ale i odborném diskurzu, zejm. při vytváření politik a sociální práci, dochází k redukování tohoto konceptu na pokračování v ekonomické aktivitě a podporu fyzické činnosti především skrze aktivity volnočasové. Tyto zúžené percepce konceptu vyvolávají značnou kritiku celého konceptu (van Dyk 2014; Hasmanová Marhánková 2013; Katz 2000; Moulaert - Paris 2013) a ve svém důsledku vytvářejí nové nerovnosti a diskriminaci těch, kteří redukované pojetí konceptu nejsou schopni naplnit.

Koncept aktivního stárnutí se blíží ve svých praktických aplikacích spíše třetímu věku, tak jak jej definoval Laslett (1989), tedy mladému stáří pojatému jako koruna života naplňována relativně zdravými a bohatými jedinci. A toto kulturní pole je sociálně strukturně podmíněno a jeho naplňování je dosahováno především střední třídou, přestože je vytoužené všemi. (Gilleard - Higgs 2005) A zatímco na úrovni společnosti obecně už Bourdieu (1984) mluví o podmíněnosti pozice $\mathrm{v}$ sociálním poli a tedy i životního stylu vlastnictvím různé míry ekonomického a kulturního kapitálu, koncept aktivního stárnutí je tř́́dně slepý.

Glorifikace určitého životního stylu a některých aktivit jako vhodnějších nezbytně favorizuje jedince, kteří inklinují $\mathrm{k}$ „žádoucímu“ chování díky svému habitu. (Hasmanová Marhánková 2014) V západních společnostech je tento tlak podpořen stárnutím silné poválečné kohorty socializované do výrazně konzumní a na mladistvost orientované společnosti. (Gilleard et al. 2005) Laslettova vize se však realitou mladého stáŕí obecně nestala, i když některé privilegované skupiny se jí svým chováním blíží. Část z nich je přitom stále ekonomicky aktivní, což by snad bylo možné chápat jako naplňování třetího věku v jeho nejčistší podobě. (Scherger et al. 2011) Pokračující ekonomická participace pak především souzní s představami vlád o řešení proměny demografické struktury populace. 
Udržování zdravého životního stylu a naplňování širokého spektra aktivit především, i když nikoliv výlučně, ve veřejném prostoru se tak zdá být jednoznačným a preferovaným rysem mladého stárí. Reálně je jejich výkon podmíněn řadou dalších strukturálních faktorů, než jen samotným věkem. Našim cílem je proto se na souvislosti věku a dalších faktorů v kontextu preferovaného životního stylu a výkonu konkrétních aktivit podívat podrobněji a odhalit, čím jsou podmíněny, zda je to samotný věk či socioekonomický status. A jaké další faktory podobu životního stylu podmiňují. Využíváme pro to dat z České republiky. Použitá data jsou prưřezová, proměnu s věkem proto nebylo možné zachytit př́padnou změnou preferencí jedince $\mathrm{v}$ čase, ale slouží nám $\mathrm{k}$ tomu širši věkové rozpětí respondentů, zahrnující jedince od 40 let, tedy ve věku středním, v mladém i pozdním stáŕí. Sledována je tak př́ípadná odlišnost dle věkových dekád. Samotné dělení na jedince v důchodu a ekonomicky aktivní by $\mathrm{v}$ tomto pohledu bylo nedostatečné, protože právě první roky po odchodu do důchodu jsou ve výše zmíněných koncepcích spojovány s největší činorodostí.

\section{Teoretická východiska}

Dominující koncept aktivního stárnutí při svém naplňování často vychází z biomedicínského pohledu na fyzickou aktivitu a zdravý životní styl a ve své podstatě tak činnosti hierarchizuje, nebot' aktivity posilující fyzickou kondici jsou více ceněné než jiné činnosti. (Lassen 2014) A aktivity, které nesledují logiku pracovní etiky (Weber 1930), jsou systematicky zneviditelňovány. (Biggs 1993) Je tedy dokazována a zvýznamňována vlastní užitečnost pro společnost, vedená narativem nestát se př́ičží pro druhé, zachovat si soběstačnost. $\mathrm{Z}$ percepce nutnosti produktivity a osobního odpovědného přístupu k vlastnímu stáŕi jako produktivnímu pak vycházejí studie měřící potenciál společnosti aktivně stárnout a její připravenost (Principi et al. 2016) či index aktivního stárnutí. (Vidovićová - Petrová Kafková 2016; Zaidi 2015) Ve svém důsledku přináší tato percepce aktivního stárnutí slepost vůči aktivitám, které primárně představu zdravého životního stylu a pracovního étosu nenaplňují. Tato percepce má tendenci upozadit $\mathrm{i}$ běžné činnosti přispívající $\mathrm{k}$ mentální a fyzické zdatnosti jedince, jako jsou pečení buchet či péče o psa. (Hasmanová Marhánková 2013)

Výše popisované vnímání aktivního stárnutí má tendenci vytvářet striktní dělicí čáru mezi aktivitou a pasivitou. Označení konceptu jako aktivní stárnutí totiž nutně evokuje otázku, co je tedy stárnutím neaktivním. Pasivita evokuje obraz seniora sledujícího televizi a rezignujícího na jiné činnosti a ve veřejných představách se zdá být opakem aktivního stárnutí. Vnímání aktivity v dichotomii k pasivitě, jako „dobrého“ stárnutí, vede k vnímání zdřímnutí si, sledování televize či sezení v křesle jako způsobům zastaralého, nemoderního ideálu stárnutí. (Lassen - Moreira 2014) Přitom zdřímnutí si umožňuje starším další 
aktivitu (Venn - Arber 2011), když se potřeba odpočinku v pokročilém stáří zvyšuje. (Horgas et al. 1998) Dichotomizaci aktivní vs. pasivní zřejmě vnímají i samotní senioři, pro které aktivní stárnutí ztělesňuje potřebu zůstat aktivní (mentálně, fyzicky i společensky) a právě opositum k pasivitě je rozhodující. Lidé totiž konceptualizují svůj život skrze přenesení profesních termínů do svých osobních narací. (Gubrium - Holstein 1997, 1998) Být pasivní totiž znamená zestárnout. Stáří v pohledu seniorů neurčuje chronologický věk, ale právě pasivita. (Stenner et al. 2011) Senioři přitom zřejmě rozlišují, zda je tato pasivita vynucená zdravotními problémy (Townsend et al. 2006) či ne. Bez ohledu na chronologický věk, je to právě zkušenost vzrůstající pasivity / úbytku činností, která je asociována se ztrátou vitality a tedy i pocitem stáríí. (Stenner et al. 2011) Towsend s kolegy (2006) prritom při studiu toho, jak senioři vnímají ostatní seniory, zjistila, že pasivita těch, kterým nebrání ve společenských aktivitách zdravotní problémy, je percipována výrazně negativně. Vnímají tento př́stup jako vzdání se, rezignaci. Autoři tento „typ“ seniorů označili „ničemové" (villains), s tím že pro participanty šlo typicky o bezejmennou masu, charakterizovanou brbláním, stěžováním si a neaktivitou. „Ničemové“ jsou v ostrém kontrastu, k druhé skupině - „hrdinům“, kteří zůstávají optimističtí i tváří v tvář potížím a nevzdávají se. Jak však Townsend s kolegy (2006) upozorňují, síla těchto př́iběhů stereotypizaci spíše posiluje, než oslabuje. „Ničemové“ jsou totiž vnímáni jako „ti druzí“ a jsou jim připsány negativní stereotypy stáŕí. Podobně Hasmanová Marhánková (2013) v českém prostředí identifikovala mezi participantkami center pro seniory distingování skupin seniorů na základě činorodosti, kdy neaktivita je vnímána jako individuální selhání. Lidé totiž usilují být aktivní, proto aby dokázali, že nejsou „skutečně“ staří. (Calasanti - King 2005) Koncept aktivity ve své snaze o přeznačení negativních konotací stárnutí, ztrácí samotné stárí ze zřetele. Stáří jsou tak sice připsány pozitivnější obsahy, ale pouze dokud jako stáří nevypadá. (Ibid.)

A jak už bylo výše zmíněno, pro naplnění ideálu nestačí pouze být aktivní, ale věnovat se „těm správným“ činnostem. $Z$ pohledu seniorů jsou to především volnočasové aktivity, koníčky a kroužky, jak se zdá z výzkumu Hasmanové Marhánkové (2013). Geronotologie však jasné vymezení ,aktivity“ nemá (Katz 2000), přestože jde o časté výzkumné téma. Ve své podstatě je měření aktivity nemožné, protože činnosti vždy překračují jakékoliv rámce a zařazení. (Ibid) Diskurz „správných“ činností a jednání je silně prítomen i ve způsobu fungování denních center pro seniory a u pobytových služeb. Davidson s kol. (2003) tak mohou vidět řešení malé participace mužů v denních centrech pro seniory v možnosti dát si k obědu pivo či zahrát si snooker.

Přestože redukovaná pojetí aktivního stárnutí ve své podstatě naši proměnu $\mathrm{s}$ věkem popírají, je zřejmé, že samotné stárnutí proměnu aktivit přináší. $\mathrm{S}$ tím, jak lidé stárnou, mění se jejich aktivity v závislosti na proměně jejich preferen-

Sociológia 51, 2019, č. 2 
cí, omezeních schopností a zdraví. A tyto změny jsou individuálně podmíněné, může jít o výčet aktivit, které jedinec vykonává, stejně jako o způsob, kterým je vykonává či jejich trvání a frekvenci. (Verbrugge et al. 1996) Řada aktivit, zejm. těch zvýznamňovaných současnými diskurzy, je závislá na určité minimální úrovni funkční zdatnosti a mobility. (Stalvey et al. 1999) Věková diferenciace činností je podmíněna také tím, že odlišné věkové kohorty zažily ve svém mládí rozdílnou kulturu volného času. (Cutler - Hendricks 1990) Spektrum činností je tedy i generačně podmíněné.

$\mathrm{Na}$ základě výzkumů využití času v průběhu dne je rozlišováno několik základních typů činností obvykle označovaných jako nutné (obligatory, tj. nezbytné pro přežití a zachování - péče o sebe sama, spánek, chůze,...), committed tedy produktivní role a údržba domácnosti a volnočasnové (discretionary) aktivity. (Verbrugge et al. 1996) Podobně Klumb a Baltes (1999) využívají stejného dělení jen s názvoslovím regenerativní, produktivní a konzumní činnosti. Podíl těchto typů činností na celkovém objemu během dne je v průběhu životního běhu proměnlivý. Ve všech př́ípadech jde o snahu co nejlépe zachytit veškeré činnosti dne a klasifikovat je a jejich výčet je tak nutně normativní.

Výrazným mezníkem časových dispozic a náplně dne je odchod do starobního důchodu, který obvykle přináší výrazné navýšení disponibilního času a zároveň výrazné snížení př́ijmů. Starobní důchod obecně vede $\mathrm{k}$ rozvolnění hranic práce a volnočasových aktivit. (Allen - Chin-Sang 1990) Přesto volnočasové aktivity, především sledování televize a četba, zabírají v seniorském věku přibližně polovinu času. (Horgas et al. 1998) Sociálně podmíněné nerovnosti v aktivitách však mají tendenci přetrvávat i v důchodovém věku. (Scherger et al. 2011) A podobně jako nemůžeme mluvit o homogenní skupině seniorů, ale spíše o jejich extrémní heterogenitě, nemůže mluvit ani homogenní střední třídě. Sociální prostor není užíván monolitickými entitami, ale jsou v něm systematické symbolické tenze. (Jarness 2017) Sociální identita totiž spočívá na rozdílech (Bourdieu 1984) a sociální hranice mezi tř́́dami i uvnitř nich jsou upevňovány a racionalizovány skrze symbolické hranice. (Lamont Molnár 2002) Ty jsou ustavovány a upevňovány právě konkrétním poměrem vlastnictví různých druhů kapitálů, tedy kapitálu ekonomického v podobě finančních zdrojů, kulturního odvozeného především z dosaženého formálního vzdělání a také kapitálu sociálního, tedy sociálních sítí, které je možné využít v prípadě potřeby. Což je v kontextu stárnutí mimořádně důležité, protože se mohou stát zdrojem přeneseného aktérství. (Béhague et al. 2008) Pozice jedince v sociálním poli daná jeho vlastnictvím kapitálů pak dává dispozici, či jinými slovy znamená vyšší pravděpodobnost určité preference životního stylu, koníčků, hudby, ale i politiky atd. (Bourdieu 1984) Toto však pro prostředí českých seniorů potvrzeno nemáme. 
Výběr aktivit je tedy podmíněn pozicí jedince v sociálním poli. Lidé $\mathrm{s}$ vyšším vzděláním a kvalifikovanějším zaměstnáním mají větší pravděpodobnost $\mathrm{s}$ věkem zintenzivnit svoje volnočasové aktivity či začít nové, zatímco lidé z nižších tříd mají pravděpodobnost se činnostem věnovat méně. (Scherger et al. 2011) Vzdělání, jako základní složka kulturního kapitálu, pak přináší i vyšší míru produktivní činnosti, ovšem pouze u žen nikoliv u mužů. (Klumb - Baltes 1999) Vzdělání totiž přispívá především k některým typům produktivní aktivity, jako např. dobrovolnictví. (Herzog et al. 1989; Wilson 2000) Kulturní kapitál je nezbytnou podmínkou pro zájem, pochopení a užívání si mnoha druhů kultury. Sociální habitus pak činí různé formy kulturní participace více či méně atraktivními. (Scherger et al. 2011) Kultura také hraje významnou roli v Laslettově (1989) vizi třetího věku, kdy lidé ve třetím věku mají významně přispívat k zachování kulturních institucí.

Kromě kulturního a ekonomického kapitálu se v kontextu stárnutí zdá být vlivný i kapitál sociální. (Lin 2017) Přínos aktivní participace životní spokojenosti je podmíněn mírou sociálního kapitálu, respondenti bez smysluplných sociálních vztahů tak nejvíce profitují z velké diverzity aktivit, ale lidé $\mathrm{s}$ velkým množstvím sociálních vztahů mají z aktivní participace relativně menší nárůst životní spokojenosti. (Litwin - Stoeckel 2014) Dle zjištění Silverstein a Parker (2002) je maximalizace participace na aktivitách užívána seniory jako adaptační strategie kompenzující sociální a fyzické deficity. Senioři, kteř́ zvýšili svoji participaci v aktivitách bez ohledu na jejich typ, vykazovali zlepšení svých životních podmínek.

Iso-Ahola a kol. (1994) ukázali odlišný vliv věku na různé typy aktivit. Zatímco počet lidí začínajících se věnovat fyzicky náročný aktivitám či venkovním aktivitám $\mathrm{s}$ věkem klesá, dochází $\mathrm{k}$ výraznému nárůstu počtu těch, kteří začali nějaké nové hobby či domácí činnost. Tyto výsledky potvrdili i Scherger s kolegy (2011), kteří dokazují, že odchod do důchodu typicky znamená více času věnovanému nějaké činnosti doma, nějakému koníčku. Oproti mladším lidem se senioři průměrně méně věnují placené práci a náročným fyzickým činnostem (Gauthier - Smeeding 2003), v pokročilém stáří pak klesá obecně výkon všech produktivních činností i činností konzumních. (Klumb - Baltes 1999; Scherger et al. 2011) Nutno však poznamenat, že dle Klumb a Baltes (1999) tvoří produktivní aktivity $16 \%$ denní náplně i v pokročilém věku. A také, že k úbytku venkovních aktivit obecně dochází až kolem 80 let. (Scherger et al. 2011) Ve vysokém stáří také narůstá objem času věnovaný péči o sebe, spánku a odpočinku. (Verbrugge et al. 1996) Senioři tráví množství času činnostmi vázanými na domov a rodinu, zájmovými činnostmi a religiózní praxí. (Vidovićová - Petrová Kafková 2012) Některé studie indikují i navýšení času tráveného o samotě. Studie Silverstein a Parker (2002) ze švédského prostředí dokládá, že i po 80 roce si mnozí zachovávají značné množství volnoča- 
sových aktivit a více než třetina jejich množství dokonce navyšuje. Spektrum volnočasových aktivit je podmíněno disponibilními zdroji a časem (Tinker 2014) a toto vysvětluje i většinu genderově a věkově podmíněných rozdílů v aktivitách. (Klumb - Baltes 1999) Kromě financí a času jsou determinantami také velikost obce a prostorová mobilita. (Scherger et al. 2011)

Dle Scherger a kolegů (2011) se mladí lidé, více než ostatní, účastní kulturních akcí, zatímco koníčky jsou doménou především mladších seniorů. Mladé seniorky také tráví nejvíce času ze všech skupin prací v domácnosti (Klumb Baltes 1999), což je zřejmě důsledek genderových rozdílů, kdy „ženy neodcházejí do důchodu“, pouze placenou práci vymění za větší péči o domácnost. (Skucha - Bernard 2000) Zatímco mužům totiž život s partnerkou přináší méně času věnovaného produktivním aktivitám a nárůst volnočasových aktivit, pro ženy to platí obráceně. (Klumb - Baltes 1999) Život bez partnera pak přináší vyšší participaci na kulturních akcích a členství v klubech, nemá však vliv na koníčky. (Scherger et al. 2011)

Z výše uvedeného vyplívá, že naplňování různých druhů aktivit se s věkem mění a nemusí vždy nutně s věkem pouze klesat. Podstatný vliv na výkon různých činností se zdají mít i míra kulturního, ekonomického i sociálního kapitálu. Tato zjištění budeme níže ověřovat $\mathrm{v}$ českém prostředí. Pro zachycení vlivu věku se nesoustředíme pouze na seniorskou populaci, ale zahrneme i mladší kohorty, což nám umožní lepší pochopení vlivu věku. Naše zjištění jsou však limitována průřezovou povahou dat, což nám neumožní rozlišit, zda jsou zjišstěné rozdíly skutečně důsledkem stárnutí či jde o rozdíly generační.

\section{Metodologie a data}

Výše uvedené otázky o vlivu věku a kapitálů na aktivitu budeme zodpovídat pomocí sekundární analýzy dat $\mathrm{z}$ výběrového šetření „Spotřeba a spotřebitelé ve vyšším věku““3. Sběr dat byl realizován v listopadu a prosinci 2011 a celkově byla získána data o 1443 respondentech. Data byla sbírána kvótním výběrem s využitím metody PAPI, kvótními znaky bylo pohlaví, věk, vzdělání, kraj a velikost obce. Sběr byl zaměřen na populaci 40letou a starší, respondentů 60letých a starších je $46 \%$. Podrobnější charakteristika vzorku viz Tabulka č. 1. Vzhledem $\mathrm{k}$ tomu, že data byla získána kvótním nikoliv náhodným výběrem a vzorek je relativně malý, jsme omezeni v možnostech aplikace statistického modelování založeného na pravděpodobnostním základu. (Soukup 2006; Soukup - Rabušic 2007) Naše analýzy se proto omezí na deskriptivní analýzy a vzájemné korelace proměnných, tyto techniky jsou však pro zodpovězení výzkumné otázky adekvátní.

\footnotetext{
${ }^{3}$ Výběrové šetření bylo uskutečněno v rámci projektu č. DC5/2011 „Starší spotřebitelé a spotřeba ve vyšším věku“ podpořeném Ministerstvem práce a sociálních věcí.
} 
Tabulka č. 1: Základní sociodemografické charakteristiky souboru

\begin{tabular}{|c|c|c|c|}
\hline & & $\%$ & $\mathbf{N}$ \\
\hline \multirow{5}{*}{ Věk } & 40-49 let & 26 & 374 \\
\hline & 50-59 let & 28 & 402 \\
\hline & 60-69 let & 25 & 366 \\
\hline & $70-79$ let & 14 & 195 \\
\hline & $80+$ let & 7 & 106 \\
\hline \multirow{2}{*}{ Pohlaví } & muži & 47 & 677 \\
\hline & ženy & 53 & 766 \\
\hline \multirow{4}{*}{ Vzdělání } & žs & 23 & 335 \\
\hline & vyučen(a) & 38 & 552 \\
\hline & sš & 22 & 319 \\
\hline & vš & 16 & 237 \\
\hline \multirow{2}{*}{ Žije s partnerem } & ano & 63 & 908 \\
\hline & ne & 37 & 535 \\
\hline
\end{tabular}

Poznámka: Součty v jednotlivých kategoriích se nemusejí rovnat celkovému N nebo 100 \% v důsledku chybějících odpovědí, případně zaokrouhlování.

Vztah k aktivitě je sledován ve dvou podobách, jednak konkrétními činnostmi, kterým se jedinec věnuje a také obecnějším postojem k pro-aktivnímu životnímu stylu ve vlastním stárí. Postoj $\mathrm{k}$ preferovanému životnímu stylu $v$ důchodu byl dotazován takto: ,Jak by měl podle Vás vypadat ideální život v důchodu?", kdy respondenti volili jednu z následujících variant: 1) di̊chod jako čas plně věnovaný rodině nebo druhým lidem (21\%), kterou dále označujeme jako „život pro druhé"; 2) život v důchodu stejný jako před di̊chodem zaměstnání a řada různých aktivit (11\%) (tj. dále zkráceně zaměstnáni); 3) důchod jako čas věnovaný predevším sobě, svým zálibám a rozvoji vlastní osoby (31\%) (tj. seberozvoj); 4) di̊chod jako čas pohody, strávený u televize nebo čtením novin, žádné náročné akce (19\%) (tj. relaxace); 5) spousta cestování, poznávání nových věcí a aktivní společenský život (18\%) (tj. činorodost). Tyto varianty byly Vidovićovou (2013) myšleny jako „weberovské čisté typy“ vycházející jak z politik stárnutí, tak z představ veřejnosti o podobě a náplni důchodového věku (Rabušic 2004). A i když se některé z variant zdají být podobné, odkazují k různým ve veřejném prostoru přítomným podobám stárnutí. 
Tabulka č. 2: Faktorové zátěže vybraných činností - položek indexů

\begin{tabular}{|c|c|c|c|}
\hline & Náročné & Tradiční & Odpočinkové \\
\hline Návštěva divadelního, tanečního představení, baletu & 0,538 & & \\
\hline Návštěva kina & 0,609 & & \\
\hline Poslouchání rádia & & & 0,382 \\
\hline Návštěva galerie, umělecké výstavy & 0,524 & & \\
\hline Vlastní umělecká činnost (hra na hudební nástroj, kresba aj.) & 0,339 & & \\
\hline Četba knih & & & 0,433 \\
\hline Četba novin a časopisů & & & 0,482 \\
\hline Vzdělávání (jazyky, odborné informace, počítače apod.) & 0,611 & & \\
\hline Hry rozvíjející myšlení jako šachy, scrable, křížovky, sudoku & & & 0,365 \\
\hline \multicolumn{4}{|l|}{ Zájmové kurzy (např. vaření ) } \\
\hline Aktivní sportování (sám/ sama provozuji) & 0,521 & & \\
\hline Návštěva sportovních akcí jako divák /divačka & & 0,478 & \\
\hline Péče o domácí zvířata, mazličky. & & 0,343 & \\
\hline Péče o užitková zviŕraata (králíci, slepice, koně apod.) & & 0,422 & \\
\hline Péěe o dům, chatu, zahradu apod. & & 0,548 & \\
\hline Hobby, kutilství & & 0,576 & \\
\hline Návštěva muzea, hradu, zámku & 0,627 & & \\
\hline Výlety, procházky & & & 0,404 \\
\hline Práce na počítači, hraní PC her & 0,588 & & \\
\hline Televizní výherní soutěže, kvízy, vědomostní soutěže & & & 0,443 \\
\hline Návštěva plesu, taneční zábavy, párty & 0,583 & & \\
\hline Návštěvy kaváren, čajoven & 0,597 & & \\
\hline Návštěvy pivnic, hospod & & 0,512 & \\
\hline Večeře v restauraci & 0,638 & & \\
\hline Návštěvy večírků, posezení s přáteli, s vrstevníky & 0,52 & & \\
\hline Posezení s rodinou & & & 0,438 \\
\hline Akce s dětmi (výlety, hry apod.) & 0,373 & & \\
\hline Pasivní odpočinek (nic nedělám, relaxuji) & & & 0,317 \\
\hline \multicolumn{4}{|l|}{ Vzájemné korelace (Pearsonovo r): } \\
\hline 1 & & ,299* & ,378* \\
\hline 2 & & &, $152 *$ \\
\hline
\end{tabular}

Poznámka: Metoda Principal Component Analysis, rotace Quartimax s Kaiserovou normalizací; KMO 0,860, $\mathrm{p}<0,001$; uvedené jsou pouze položky s faktorovu zátěží 0,3 a vyšší. * $\mathrm{p}<0,01$

Druhou sledovanou proměnnou je výčet činností, které k různým životním stylům odkazují. Ty byly zjišt’ovány následující otázkou: "Které z následujících činností jste se věnovala/a v posledním půl roce a zároveň byste je označila za své oblíbené?,“ kdy u každé položky respondent vybíral z variant ano / ne. My jsme sledovali souhlasné odpovědi. Baterie obsahuje 31 položek. Ty byly na základě výsledků faktorové analýzy rozděleny do tř́ sumačních indexů 
(jednotlivé faktorové zátěže položek viz Tabulka č. 2 níže). Některé z variant nesytily žádný $z$ faktorů a jejich frekvence byla velmi nízká, takže byly z dalších analýz vyloučeny. Položka „výlety, procházky“ shodě sytila dva indexy a byla do indexu relaxačních činností zařazena na základě meritorního významu. Procházky jsou totiž typem venkovní mobility, která zůstává zachována i ve vysokém věku a při zdravotních omezeních. (Vidovićová et al. 2013) Naproti tomu návštěva hradu či galerie vyžaduje mnohem větší úsilí včetně typicky cestování na větší vzdálenost a zvládnutí delšího času „na nohou“, tím se nám zdá zařazení mezi náročné činnosti logickým. Podobně posezení $\mathrm{s}$ rodinou může znamenat $\mathrm{i}$ krátkou návštěvu dětí či vnoučat $\mathrm{v}$ domově seniora či seniorky, zatímco posezení s práteli, vrstevníky vyžaduje větši úsilí a tím že je v položce i „návštěva večírkư", zdá se nám statistické rozdělení i meritorně správné.

První z indexů jsme nazvali index náročných činností a může nabývat hodnot 0 - 13 s průměrnou hodnotou 4,1 (medián 4). Druhý index tradičnich činností nabývá hodnot $0-6 \mathrm{~s}$ průměrnou hodnotou 2,5 (medián 2). Třetí index odpočinkových činností pak může nabývat hodnot $0-8$, s průměrem 5,7 (medián 6). Byt' se může zdát, že naplňování těchto typů činností, těchto indexů, bude závislé na velikosti místa bydliště, platí tato souvislost pouze u indexu tradičních činností a to velmi slabě. Jeho míra s velikostí města klesá (Kendallovo tau $\mathrm{b}=0,17)$. Slabou souvislost můžeme vysvětlit tím, že mezi tradičními činnostmi jsou i např. péče o domácí zviŕăata, dům či chatu a zahradu, které se často týkají i lidí z měst. Naopak bydliště v malé obci nebrání naplňování kulturních a dalších činností obsažených $\mathrm{v}$ indexu náročných činností. Malý rozdíl v naplňování tohoto typu činností mezi seniory žijícími ve městech a na venkově nalezla i Vidovićová (2018).

Ekonomická pozice byla $\mathrm{v}$ datech zjišt'ována více proměnnými na základě jejich deskriptivních analýz a vzájemných korelací byly vybrány pro naše účely tři: ekonomické postavení, dichotomizované na důchodce (47\%) a jedince pohybující se na trhu práce (53\%) a dále subjektivní bohatství, které nabývá průměrné hodnoty 4,83 (medián 5 , kdy 10 znamená bohatý). A především třídou odvozenou na základě klasifikace (posledního) zaměstnání CZ-ISCO a kategorizovanou na vyšší (7 \%), střední (46 \%) a nižší (47 \%). Proměnné spolu korelují jen slabě ${ }^{4}$ Ostatní proměnné použité v původních datech spolu s těmito vybranými naopak korelovaly silně a jejich použití by proto nepřineslo dodatečnou informaci.

K sociálnímu kapitálu pak odkazují, i když je za položky měřící přímo sociální kapitál nemůžeme považovat, dvě proměnné. Jednak otázka zda respon-

\footnotetext{
4 Hodnoty Kendallova tau C byly následující: ekonomické postavení - tř́ída $-0,15$; ekonomické postavení - subjektivní bohatství 0,177 ; tř́da - subjektivní bohatství $-0,245$. Pro všechny hodnoty platí signifikance $\mathrm{p}<0,05$.
} 
dent žije s partnerem, kterou využíváme jako zjednodušující indikátor rodinného stavu a zároveň složení domácnosti, které obojí může podstatným způsobem ovlivňovat výběr aktivit a čas jim věnovaný. V kontextu stárnutí jde pak o proměnnou zásadní. V našem souboru žije s partnerem $63 \%$ respondentů. A také $\mathrm{k}$ sociálnímu kapitálu nepř́mo odkazuje pocit osamělosti, který byl měřen na 10bodové škále, kdy můžeme předpokládat, že menší pocit osamělosti by měl odkazovat $\mathrm{k}$ vyššímu sociálnímu kapitálu a tedy pevnějšímu zapojení v sociálních sítích. Proměnná byla dotazována následovně: „Cítíte se někdy osamělý/á?“", s možností odpovědi na škále $1-10$, kdy 1 = nikdy a $10=$ stále. Osamělost nabývá v našem souboru průměru 4,3 (medián 4). Obě tyto proměnné volně odkazující k sociálnímu kapitálu spolu korelují (Pearsonovo $\mathrm{r}=0,39$, $\mathrm{p}<0,05)$. Kulturní kapitál je pak měřen nejvyšším dosaženým vzděláním jedince, tedy formálním vzděláním (viz Tabulka č. 1).

Poslední použitou kontrolní proměnnou je zdravotni stav, zjišstovaný jako subjektivní zdravotní stav deklarovaný na deseti bodové škále, jejíž krajní varianty byly označeny 1 - zcela bez zdravotních potíží a 10 - výrazné zdravotní potíže. Zdravotní stav nabývá v souboru průměru i mediánu 5.

\section{Výsledky}

\section{Preferovaný životni styl $v$ důchodu}

Životní styl v podobě větší či menší tendence $\mathrm{k}$ činorodosti či naopak klidnějším činnostem a pasivitě jsme měřili dvěma proměnnými. Jednak představou o ideálním (budoucím) způsobu života $\mathrm{v}$ důchodu a pak také typem činností, kterým se jedinec skutečně věnuje. Výsledky provedených analýz ukazují především dvě následující tendence.

Jednou z nich je větší př́íklon ke klidovějšímu způsobu trávení času s věkem $($ Eta $=0,304, \mathrm{p}<0,05), \mathrm{kdy} \mathrm{s}$ věkem dochází $\mathrm{k}$ preferenci relaxace před zaměstnáním, činorodostí a seberozvojem. Podíl respondentů preferujících život pro druhé se s věkem nemění. Pokles preference činorodých aktivit s věkem indikuje tenzi mezi představami o trávení důchodu $\mathrm{v}$ budoucnu a jeho reálnou podobou. Nebo-li lidé, které tranzice do důchodu teprve čeká, častěji doufají, že se jejich život tímto přechodem nezmění a za ideální považují značnou aktivitu a činorodost. Zatímco lidé, kteří již v důchodovém věku jsou, vnímají jako ideální méně aktivní trávení času. Zdá se, jako by se představy o činorodém trávení času $\mathrm{v}$ důchodu střetávaly s pasivnější realitou vyššího věku. Výrazný nárůst preference relaxace je patrný u nejstarší věkové kategorie 80-89letých, $45 \%$ z nich považuje relaxaci za ideální způsob trávení času ve stárí. Mezi 7079letými je to přitom jen $29 \%$ a mezi $60-69$ letými $20 \%$ a mezi mladšími kohortami $13 \%$. Výrazně intervenující proměnou totiž představuje zdravotní stav (korelace typu preferovaných aktivit a zdraví měřená pomocí Eta $=0,239, \mathrm{p}<$ $0,05)$. Zdá se proto, že se zhoršením zdravotního stavu v souvislosti s vyšším 
věkem dochází $\mathrm{k}$ přeorientování se na méně náročné činnosti a to i na úrovni představ o trávení času.

Tabulka č. 3: Preferovaný životní styl v důchodu dle sledovaných proměnných

\begin{tabular}{|c|c|c|c|c|c|c|}
\hline & & Život pro druhé & Zaměstnání & Seberozvoj & Relaxace & Činorodost \\
\hline \multirow[t]{3}{*}{ Celkem } & & $21,0 \%$ & $10,7 \%$ & $31,2 \%$ & $19,2 \%$ & $17,9 \%$ \\
\hline & $40-49$ & $16,9 \%$ & $11,9 \%$ & $31,1 \%$ & $13,1 \%$ & $26,9 \%$ \\
\hline & $50-59$ & $20,8 \%$ & $12,7 \%$ & $32,4 \%$ & $12,9 \%$ & $21,3 \%$ \\
\hline \multirow[t]{4}{*}{ Věk } & $60-69$ & $22,9 \%$ & $9,8 \%$ & $34,9 \%$ & $19,6 \%$ & $12,8 \%$ \\
\hline & $70-79$ & $24,5 \%$ & $8,3 \%$ & $27,6 \%$ & $29,2 \%$ & $10,4 \%$ \\
\hline & $80+$ & $23,3 \%$ & $6,8 \%$ & $20,4 \%$ & $44,7 \%$ & $4,9 \%$ \\
\hline & žs & $26,6 \%$ & $8,5 \%$ & $26,3 \%$ & $29,9 \%$ & $8,8 \%$ \\
\hline \multirow{4}{*}{ Vzdělání } & vyučen(a) & $18,7 \%$ & $12,5 \%$ & $31,9 \%$ & $21,1 \%$ & $15,9 \%$ \\
\hline & sš & $22,5 \%$ & $7,7 \%$ & $33,4 \%$ & $12,5 \%$ & $23,8 \%$ \\
\hline & vš & $16,5 \%$ & $13,9 \%$ & $33,5 \%$ & $8,3 \%$ & $27,8 \%$ \\
\hline & vyšší & $16,7 \%$ & $18,6 \%$ & $29,4 \%$ & $9,8 \%$ & $25,5 \%$ \\
\hline \multirow[t]{2}{*}{ Třída } & střední & $21,8 \%$ & $11,5 \%$ & $30,8 \%$ & $14,8 \%$ & $21,2 \%$ \\
\hline & nižší & $20,7 \%$ & $8,8 \%$ & $32,1 \%$ & $24,9 \%$ & $13,5 \%$ \\
\hline \multirow{2}{*}{ Pohlaví } & žena & $26,9 \%$ & $8,2 \%$ & $28,9 \%$ & $17,3 \%$ & $18,7 \%$ \\
\hline & muž & $14,5 \%$ & $13,6 \%$ & $33,7 \%$ & $21,2 \%$ & $17,0 \%$ \\
\hline \multirow{2}{*}{ Partnerství } & ne & $22,8 \%$ & $6,9 \%$ & $31,3 \%$ & $23,2 \%$ & $15,7 \%$ \\
\hline & ano & $20,0 \%$ & $13,0 \%$ & $31,1 \%$ & $16,8 \%$ & $19,2 \%$ \\
\hline \multirow{2}{*}{$\begin{array}{l}\text { Ekonomická } \\
\text { pozice }\end{array}$} & v důchodu & $23,4 \%$ & $8,3 \%$ & $31,2 \%$ & $25,5 \%$ & $11,6 \%$ \\
\hline & $\begin{array}{l}\text { ekonomicky } \\
\text { aktivní }\end{array}$ & $18,9 \%$ & $12,9 \%$ & $31,1 \%$ & $13,5 \%$ & $23,6 \%$ \\
\hline
\end{tabular}

Nezanedbatelný vliv hraje také gender (Cramerovo $\mathrm{V}=0,171, \mathrm{p}<0,05$ ). Ženy častěji než muži ( $27 \%$ vs. $15 \%)$ preferovaly důchod jako čas pro druhé, a naopak o něco méně vnímaly jako ideální životní způsob v důchodu zaměstnání $(8 \%$ vs. $14 \%)$ a relaxaci ( $17 \%$ vs. $21 \%)$. O něco méně často než muži volily také seberozvoj ( 29 vs. $34 \%$ ). Tyto rozdíly jsou na hranici statistické chyby, indikují však genderově podmíněnou rozdílnou preferenci životních stylů.

Druhá výrazná tendence je vyšší tendence k činorodosti s vyšší mírou kapitálů a tedy i vyšším socioekonomickým postavením. Konkrétně s vyšším vzděláním, vyšší třídou, prrítomností partnera, jako kvazi-indikátorem sociálního kapitálu a ekonomickou aktivitou. U vzdělání $(E t a=0,215, \mathrm{p}<0,05)$ nacházíme výrazný prííklon $\mathrm{k}$ činorodosti se vzrůstajícím vzděláním a naopak pokles preference relaxace. Třída představu ideálního života v důchodu ovlivňuje podobně, navíc však s třídou roste preference zaměstnání. Partnerství pak přináší mírný př́íklon k pro-aktivnějšímu životnímu stylu ve stáŕí, i když vzájemná 
statistická souvislost není nijak těsná $(E t a=0,121, \mathrm{p}<0,05)$. Lidé bez partnera o něco častěji volí relaxaci ( $23 \%$ vs. $17 \%)$, méně zaměstnání ( $7 \%$ vs. $13 \%)$ a činorodost (16\% vs. $19 \%$ ). Podobně vyšší pocit osamělosti (viz Tabulka 5) vede $\mathrm{k}$ větší preferenci relaxace a nižší preferenci zaměstnání a činorodosti. Přitom nepůjde pouze o vdovy, tedy převážně starší seniorky, v souboru je totiž stejně ovdovělých jako rozvedených. Ekonomická aktivita v kontrastu $\mathrm{k}$ důchodu znamená větší tendenci $\mathrm{k}$ zaměstnání a činorodosti a naopak menší preferenci relaxace. Subjektivní bohatství na první pohled stoupající tendenci k aktivitě $\mathrm{s}$ vyšším subjektivním bohatstvím potvrzuje, rozdíly jsou však pouze malé. A žádný významný rozdíl jsme nenalezli ani u pocitu osamělosti. Preferovaný životní styl se tedy zdá lišit nejen podle věku a zdraví (hraniční je přitom až pokročilé stáŕí), výrazným determinantem se potvrzuje být i míra kapitálů.

Tabulka č. 4: Preferovaný životní styl v důchodu dle subjektivního bohatství, pocitu osamělosti a zdraví (průměrné hodnoty)

\begin{tabular}{lccc}
\hline & Subjektivní bohatství & Osamělost & Zdraví \\
\hline Zaměstnání & 5,6 & 3,5 & 4,2 \\
Činorodost & 5,3 & 3,8 & 4,4 \\
Seberozvoj & 4,8 & 4,3 & 4,9 \\
Život pro druhé & 4,6 & 4,4 & 5,1 \\
Relaxace & 4,3 & 5,0 & 6,0 \\
\hline
\end{tabular}

Preferovanýživotná styl $v$ důchodu v kontextu volených činností

V dalším kroku se podívejme, jak se preferovaný životní styl v penzi projevuje v konkrétních činnostech, či v prrípadě našeho výčtu spíše koníčcích, které lidé vykonávají. Budeme tedy nejdř́ve sledovat vztah preferovaného životního stylu a vykonávaných činností.

Síla vztahu se u jednotlivých typů činností liší, nejtěsnější je u náročných aktivit $(\mathrm{Eta}=0,327, \mathrm{p}<0,05), \mathrm{u}$ tradičních a odpočinkových je naproti tomu jen slabá $(E t a=0,132$ resp. $0,144, p<0,05)$. Nejvyšší variabilita je u náročných činností, kde rozdíl mezi nejaktivnějšími a nejméně aktivními dosahuje 40,8 \% možné variability. U ostatních dvou typů činností je variabilita podstatně menší a rozdíl mezi krajními pozicemi dosahuje pouze 3,6 resp. 4,8 \% možné variability těchto indexů. U všech tři je však, byt' v různé míře patrné, že lidé preferující činorodé stáří mají nejvyšší hodnoty indexů činností, věnují se tedy nejvíce aktivitám. Naopak lidé preferující relaxaci mají i nejnižší průměrnou hodnotu náročných aktivit. 
Graf č. 1: Průměrná hodnota indexů činností v kontextu preferovaného životního stylu v důchodu

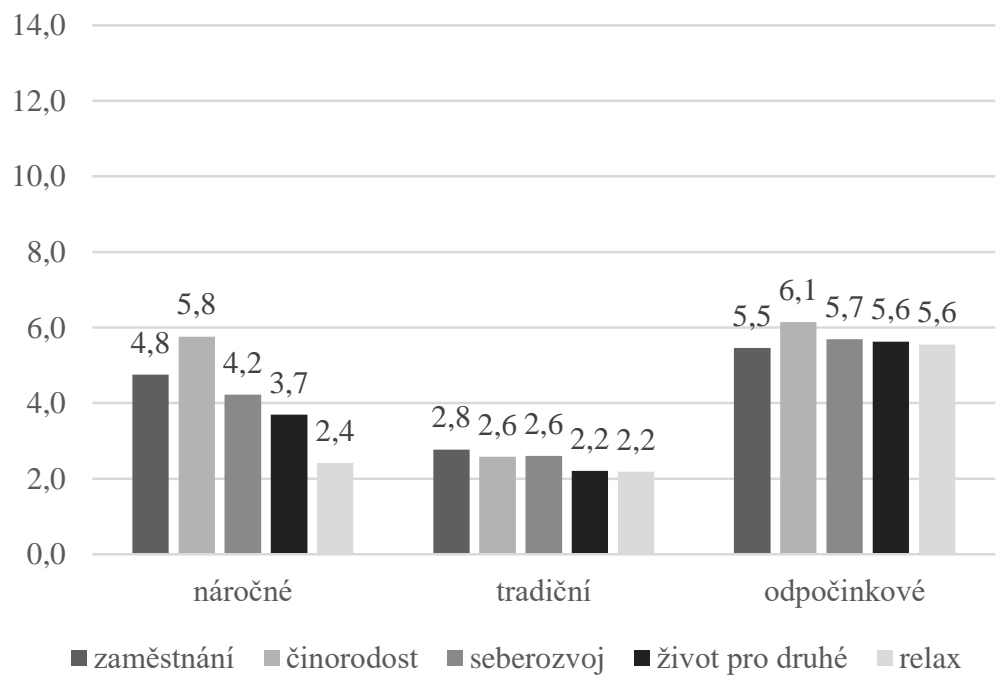

Preference různých typů činností

Nyní se podívejme, jak jsou hodnoty sledovaných typů činností podmíněné charakteristikami respondentů. Nejdříve se zaměříme na vliv věku. Ten je silný především u náročných činností, jejichž průměrná hodnota lineárně klesá se stoupajícím věkem (40-49letí $\varnothing 5,9,80+$ let $\varnothing 1,3)$. Tradiční aktivity variují $\mathrm{s}$ věkem o něco méně. Lidé 40-49letí mají průměrně 2,8 tradičních aktivit, zatímco lidé 80letí a starší jen 1,6. Míra odpočinkových aktivit se podle věku neliší. Naopak gender má vliv na tradiční a odpočinkové činnosti, kdy muži více preferují tradiční činnosti a ženy odpočinkové. Rozdíl v míře aktivit je mezi lidmi žijícími s partnerem a bez partnera. Lidé žijící s partnerem mají vyšší průměrnou hodnotu náročných $(4,6$ vs. 3,3$)$ i tradičních $(2,8$ vs. 1,9$)$ aktivit. Do vlivu partnerství na spektrum činností však výrazně intervenuje věk respondenta.

Také vzdělání diversifikuje všechny tři typy činností a to způsobem, že se stoupajícím vzděláním stoupá i průměrná hodnota všech tř́ typů činností. Navíc je patrný výrazný předěl mezi středoškoláky bez maturity a s maturitou. U tradičních činností je tomu jinak, odlišují se lidé se základním vzděláním $(\varnothing 2,0)$ od všech vyšších stupňů vzdělání, které shodně dosáhly průměru 2,6. Odpočinkové činnosti pak opět rozdělují respondenty na ty, kteří mají alespoň maturitu a respondenty s nižším vzděláním. Rozdíly jsou v tomto prrípadě malé, ale ne zanedbatelné. Podobně silně intervenuje i trrída. U tradičních činností, 
jsou rozdíly mezi tř́dami nevýznamné, ale u odpočinkových nacházíme rozdíl mezi nižším spektrem odpočinkových činností lidí s nižší třídou a větším spektrem u ostatních dvou tříd. Nárůst náročných činností s vyšší trrídou je pak značný.

Tabulka č. 5: Průměrné hodnoty indexů činností dle sledovaných proměnných

\begin{tabular}{llccc}
\hline & & Náročné & Tradiční & Odpočinkové \\
\hline \multirow{4}{*}{ Věk } & $40-49$ & 5,9 & 2,8 & 5,6 \\
& $50-59$ & 4,7 & 2,7 & 5,7 \\
& $60-69$ & 3,5 & 2,4 & 5,9 \\
& $70-79$ & 2,3 & 2,1 & 5,9 \\
\multirow{4}{*}{ Vzdělání } & $80+$ & 1,3 & 1,6 & 5,4 \\
& žs & 2 & 2 & 5,5 \\
& vyučen(a) & 3,7 & 2,6 & 5,6 \\
\multirow{4}{*}{ Tř́da } & sš & 5,3 & 2,6 & 5,9 \\
& vš & 6,6 & 2,6 & 6 \\
\multirow{4}{*}{ Pohlaví } & vy̌ší & 6,6 & 2,8 & 6,0 \\
& stř̌ední & 4,9 & 2,4 & 5,9 \\
Partnerství & nižší & 2,9 & 2,5 & 5,5 \\
& žena & 4,2 & 2 & 6 \\
\multirow{2}{*}{ Ekonomická pozice } & muž & 4,1 & 3 & 5,4 \\
& ne & 3,3 & 1,9 & 5,7 \\
& ano & 4,6 & 2,8 & 5,7 \\
& v důchodu & 2,8 & 2,1 & 5,8 \\
& ekonomicky aktivní & 5,3 & 2,8 & 5,7 \\
\hline
\end{tabular}

Vzhledem ke značnému vlivu trrídy i věku nepřekvapí značný rozdíl ve spektru činností mezi ekonomicky aktivními a důchodci, kdy důchodci mají výrazně nižší spektrum náročných činností $(2,8$ vs. 5,3$)$ i tradičních činností ( 2,1 vs. 2,8$)$, v odpočinkových se neliší. Ještě silnější je pak vztah sledovaných indexů se subjektivním bohatstvím. Ve všech případech platí, že s rostoucím pocitem bohatství roste množství činností, kterým se jedinec věnuje. Nejsilnější je tento vztah $u$ indexu činností náročných (Pearsonovo $R=0,351, p<0,05)$, o něco slabší pak u indexu činností tradičních (Pearsonovo $\mathrm{R}=0,212, \mathrm{p}<0,05$ ). Index činností odpočinkových je vzhledem ke své malé finanční náročnosti ovlivněn subjektivním bohatstvím jen slabě, přesto však statisticky významně (Pearsonovo $\mathrm{R}=0,132, \mathrm{p}<0,05$ ).

A je logické, že vztah můžeme nalézt i mezi spektrem činností a pocitem osamělosti, jako kvazi-indikátorem sociálního kapitálu. U všech tř́ indexů vede pocit osamělosti $\mathrm{k}$ menší intenzitě činností. Silný je tento vztah zejména u činností náročných (Pearsonovo $\mathrm{R}=0,264, \mathrm{p}<0,05$ ) a tradičních (Pearsonovo $\mathrm{R}=$ 
$0,201, \mathrm{p}<0,05)$. U činností odpočinkových je vztah velmi slabý, ale přesto přítomný, což se nám zdá být jako podstatné zjištění (Pearsonovo $\mathrm{R}=0,059$, $\mathrm{p}<0,05)$.

Subjektivní zdraví pak nejvíce ovlivňuje činnosti náročné, zde můžeme nalézt silnou statistickou souvislost (Pearsonovo $\mathrm{R}=0,420, \mathrm{p}<0,05$ ). Lidé $\mathrm{s}$ horším zdravím tedy naplňují náročné činnosti výrazně méně než lidí bez zdravotních omezení, což je logický výsledek. Slabou souvislost jsme pak nalezli mezi zdravím a tradičními činnostmi (Pearsonovo $\mathrm{R}=0,211 \mathrm{p}<0,05$ ). Naopak odpočinkové činnosti nejsou zdravotním stavem podmíněné (Pearsonovo $\mathrm{R}=0,053)$. Tato souvislost vytvořených indexů se zdravotním stavem nám navíc potvrzuje vhodnost rozdělení činností do indexů.

Můžeme tedy shrnout, že vyšší míra ekonomického, sociálního i kulturního kapitálu přináší vyšší spektrum činností a to i činností vnímaných jako pasivní (četba, sledování televize, ...), naopak zvyšující se věk představuje pro větší pestrost činností bariéru. Nižší spektrum činností však přináší až pokročilé stáŕí, nikoliv přechod do důchodu. Gender pak na výkon činností nepůsobí, přestože nabízený výběr činností odkazuje spíše $\mathrm{k}$ tradičně mužským možnostem a opomíjí řadu činností, kterým se věnují ve stáří ženy. Tento výsledek přitom není v souladu s respondenty deklarovaným ideálním životním způsobem ve stáří, kde se ženy zdály být aktivnějšíi. $Z$ těchto rozporných výsledků můžeme usuzovat, že u žen dochází $\mathrm{k}$ většímu nesouladu mezi představami o životním způsobu a jeho konkrétní realizací. Podstatným je také zjištění, že zatímco u náročných činností variuje jejich spektrum v závislosti na věku, zdraví i míře sledovaných kapitálů, činnosti odpočinkové věk a zdraví nedeterminují, zatímco míra kapitálů a gender ano.

\section{Závěr a diskuze}

Předkládaný text se soustředil na souvislosti životního stylu, činností s věkem a mírou ekonomického, sociálního a kulturního kapitálu. Význam aktivity zejména a ne jen ve stáŕí dokazují mnohé geriatrické i psychologické výzkumy. Aktivita se zdá přispívat $\mathrm{k}$ zachování mentálního i fyzického zdraví a tím i vyšší kvalitě života a prospěšné se zdá být zejm. zapojení v širokém spektru činností a sociálních vazeb. (Baltes 2009; Baltes - Baltes 1993; Fabrigoule et al. 1995; Menec - Chipperfield 1997; Silverstein - Parker 2002) Aktivnější životní styl se tedy bez ohledu na konkrétní vykonávané činnosti zdá být vhodnou adaptační strategií v průběhu celého životního běhu. Důraz na aktivitu je i nedílnou součástí soudobých konceptů stárnutí, zejména konceptu aktivního stárnutí (WHO 2002), v jejichž redukovaných podobách bývá adorována především náročnější fyzická aktivita a který má být celoživotní přípravou na stáŕí. Benefit pro jedince však přináší nejrůznější typy aktivit, jak ukazují studie citované výše. Současný důraz na aktivitu pak ve svém důsledku vytváŕí norma- 
tivní tlak na naplňování „správné“ podoby stárnutí, na konzumaci „správných“ aktivit navzdory věku. A přestože je situace ve středoevropských zemích odlišná od USA a Velké Británie, tlak na naplňování a oceňování specifického modelu stárnutí je zde také patrný. (Hasmanová Marhánková 2013) Na druhou stranu může stárnutí kvůli postupnému fyzickému a mentálnímu úbytku znamenat opouštění nejrůznějších činností. Nelze ani opomenout, že míra aktivity je veskrze individuální a existují indicie ukazující normální rozložení, tedy sledující Gaussovu křivku aktivity v populaci. (Vidovićová 2005)

Na základě výsledků našich analýz můžeme konstatovat, že představa ideálního životního stylu je výrazně závislá na věku a potažmo tedy i zdravotním stavu. Výraznější proměnu však přináší až pokročilé stáří. Silný je zejména rozpor mezi vlastní představou o aktivním trávení seniorského věku mezi mladšími respondenty a př́íklon $\mathrm{k}$ pasivnějším činnostem a věnovaní se druhým u respondentů starších. Toto zjištění můžeme interpretovat jako doklad určité platnosti teorie vyvázání (Cumming - Henry 1961), přestože je právě koncepty aktivity zpochybňována. Prưřezová povaha dat nedovoluje identifikovat, zda máme vysvětlení hledat $\mathrm{v}$ rozdílech kohortních či generačních. Př́klon $\mathrm{k}$ pasivitě by proto bylo vhodné sledovat na dostatečně dlouhé časové řadě panelových či alespoň longitudinálních dat. Takové však zatím, pokud je nám známo, nemáme v České republice $\mathrm{k}$ dispozici.

Druhým zjištěním je větší př́íklon $\mathrm{k}$ aktivnějšímu životnímu stylu u jedinců $\mathrm{s}$ vyšší mírou kapitálů. Zásadní se zdá být míra ekonomického a kulturního kapitálu, působí však i kapitál sociální. Potvrzuje se tak trvající platnost starší studie Kuchařové, která konstatovala, že „význam vzdělání pro společenské postavení a zapojení jednotlivce se nevztahuje jenom na dobu ekonomické aktivity, ale v podstatě se stejnou důležitostí i k seniorskému věku“. (Kuchařová 2002: 57) A ukazuje také na velmi postupný a mírný pokles aktivity $\mathrm{s}$ věkem u vysokoškolsky vzdělaných jedinců. Podobně Vidovićová (2005) na stejných datech zjišt'uje, že nízká míra aktivity je spojená s nižším vzděláním, vyšším věkem a některými indikátory nižšího well-being, jako např. osamělostí. Zásadní význam vzdělání, jako základní složky kulturního kapitálu, je i v souladu se studií Schergera s kolegy (2011). Ti v britském prostředí s pomocí dat z English Longitudinal Study of Ageing ukázali, že vzdělání, zaměstnání a bohatství hrálo zásadní roli ve zkoumaných typech volnočasových aktivit a nejvíce pro participaci na kulturních akcích. Vzdělání, jako nejsilnější složku kulturního kapitálu, přitom identifikovali jako nejsilnější determinant aktivit, který částečně ovlivňuje i rozdíly mezi věkovými skupinami. (Scherger et al. 2011) Není to však jen kulturní kapitál, ale i kapitál ekonomický a sociální, co pestrost činností $\mathrm{v}$ českém prostředí podmiňují. Ve středoevropském prostoru není přímo životnímu stylu seniorů věnována velká pozornost a obvykle je případně zkoumán bez ohledu na třídu, vzdělání a další důležité stratifikační 
faktory (Bendikova - Bartík 2015), jasné vnesení stratifikace do těchto analýz se nám proto zdá důležité.

Za třetí jsme potvrdili mírnou genderovou diferenciaci v preferenci životního stylu, můžeme však konstatovat, že tyto rozdíly jsou spíše menší. Ženy mají nižší šanci než muži volit jako preferovaný životní styl relaxaci, častěji než muži však volí věnování se druhým, což potvrzuje stereotypní vnímání mužské a ženské role v rodině. V souladu s genderovými stereotypy však není konkrétní podoba životního stylu, tedy volba koníčků a volnočasových činností. Zde můžeme konstatovat, že ženy se stejně často jako muži věnují aktivitám, které jsme označili jako „náročné“ (např. vzdělávání, sportování, kultura, práce na PC...) a které odkazují především k Laslettově (1989) představě třetího věku. Kromě toho mají ženy větší spektrum „odpočinkových“ činností, zatímco muži naopak aktivit „tradičních“, i když rozdíly jsou opět spíše menší. Jen malou genderovou diverzitu v činnostech dle jejich typu zaznamenala i Kuchařová (2002).

Čtvrtým zjištěním je výrazný vliv míry kapitálů také na konkrétní aktivity, kterým se jedinec věnuje. Jakkoliv je znám vliv vzdělání a tř́́dy na podobu trávení volného času, jako překvapivý chápeme tento vliv na spektrum „odpočinkových“ činností. I když jsou zjištěné rozdíly relativně malé, můžeme konstatovat, že lidé s nižším vzděláním a nižším ekonomickým a sociálním kapitálem mají i menší spektrum odpočinkových aktivit. Výrazný vliv vzdělání na spektrum činností je v souladu se zjištěními Kuchařové (2002) a Vidovićové (2005), na rozdíl od Vidovićové (2005) však ukazujeme i značný vliv třídy.

Jak však připomínají Vergrugee s kolegy (1996) individuální rozdíly mezi lidmi jsou mnohem větši než ty zpưsobené např. stárnutím. Změny v aktivitách mají tendenci být postupné a mají tendenci zachovávat tak konzistenci i dynamiku v životě. Navíc můžeme připomenout, že podle WHO (1998) jsou prospěšné všechny činnosti či způsoby participace ve společnosti, které přispívají k subjektivní kvalitě života jedince, bez ohledu na to jak souzní s aktuální představou o ideální podobě stárnutí. A aktivní stárnutí by mělo být senzitivní $\mathrm{k}$ tř́iním, kulturním, genderovým, etnickým a dalším odlišnostem. (Walker 2002)

Marcela Petrová Kafková je socioložka a výzkumnice Ústavu populačnich studii Fakulty sociálnich studií Masarykovy univerzity. Dlouhodobě se věnuje sociologii stárnutí a sociální gerontologii. Její výzkumný zájem se soustredí předevšim na oblast populačního stárnutí, koncept aktivního stárnutí a jeho reprezentaci a také environmentální gerontologii.

\section{LITERATURA}

ALLEN, K. R. - CHIN-SANG V., 1990: A Lifetime of Work: The Context and Meanings of Leisure for Aging Black Women. The Gerontologist 30(6):734-740. 
BALTES, P. B., 2009: Stář́ a stárnutí jako oslava rovnováhy: mezi pokrokem a důstojností. In: P Gruss (ed.): Perspektivy stárnutí: z pohledu psychologie celoživotního vývoje. Praha: Portál, s. 11-25.

BALTES, P. B. - BALTES M. M., 1993: Successful Aging: Perspectives from the Behavioral Sciences. Cambridge University Press.

BÉHAGUE, D. P. - KANHONOU, L. G. - FILIPPI, V. - LĖGONOU, S. - RONSMANS, C., 2008: Pierre Bourdieu and Transformative Agency: A Study of How Patients in Benin Negotiate Blame and Accountability in the Context of Severe Obstetric Events. Sociology of Health \& Illness 30(4):489-510.

BENDIKOVA, E. - BARTÍK, P., 2015: Selected Determinants of Seniors Lifestyle Journal of Human Sport and Exercise. Journal of Human Sport and Exercise 10(3):805-814.

BIGGS, S., 1993: Understanding Ageing: Images, Attitudes and Professional Practice. Open University Press.

BOURDIEU, P., 1984: Distinction: A Social Critique of the Judgement of Taste. Harvard University Press.

CALASANTI, T. - KING, N., 2005: Firming the Floppy Penis. Men and Masculinities $8(1): 3-23$.

CUMMING, E. - HENRY W. E., 1961: Growing Old, the Process of Disengagement. Basic Books.

CUTLER, S. J. - HENDRICKS, J., 1990: Leisure and Time Use Across the Life Course. Handbook of aging and the social sciences 3:169-185.

DAVIDSON, K. - DALY, T. - ARBER, S., 2003: Older Men, Social Integration and Organisational Activities. Social Policy and Society 2(2):81-89.

van DYK, S., 2014: The Appraisal of Difference: Critical Gerontology and the ActiveAgeing-Paradigm. Journal of Aging Studies 31:93-103.

FABRIGOULE, C. et al., 1995: Social and Leisure Activities and Risk of Dementia: A Prospective Longitudinal Study. Journal of the American Geriatrics Society 43(5):485-490.

GAUTHIER, A. H. - SMEEDING, T. M., 2003: Time Use at Older Ages: Cross-National Differences. Research on Aging 25(3):247-274.

GILLEARD, Ch. - HIGGS, P. - HYDE, M. - WIGGINS, R. - BLANE, D., 2005: Class, Cohort, and Consumption: The British Experience of the Third Age. The Journals of Gerontology Series B: Psychological Sciences and Social Sciences 60(6):305-310.

GILLEARD, Ch, - HIGGS, P., 2005: Contexts of Agieng. Class, cohort and Community. Cambridge: Policy Press.

GUBRIUM, J. F. - HOLSTEIN, J. A., 1998: Narrative Practice and the Coherence of Personal Stories. Sociological Quarterly 39(1):163-187.

GUBRIUM, J. F. - HOLSTEIN, J. A., 1997: The New Language of Qualitative Method. Oxford University Press on Demand.

HASMANOVÁ MARHÁNKOVÁ, J., 2013: Aktivita jako projekt. Diskurz aktivního stárnutí a jeho odezvy v životech českých seniorů a seniorek. Studie. Praha: SLON.

HASMANOVÁ MARHÁNKOVÁ, J., 2014: Aktivní stárnutí jako idea, nástroj a kapitál. kde hledat kořeny úspěchu koncepty aktivního stárnutí? Sociální studia (3):13-29.

HAVIGHURST, R. J. - ALBRECHT, R., 1953: Older People. Oxford, England: Longmans, Green.

HERZOG, A. R. - KAHN, R. L. - MORGAN, J. N. - JACKSON, J. S. - ANTONUCCI, T. C., 1989: Age Differences in Productive Activities. Journal of Gerontology 44(4):129138. 
HORGAS, A. L. - WILMS, H. U. - BALTES, M. M., 1998: Daily Life in Very Old Age: Everyday Activities as Expression of Successful Living". The Gerontologist 38(5):556568.

ISO-AHOLA, S. E. - JACKSON, E. - DUNN, E., 1994: Starting, Ceasing, and Replacing Leisure Activities Over the Human Life-span. Journal of Leisure Research 26(3):227249.

JARNESS, V., 2017: Cultural vs Economic Capital: Symbolic Boundaries within the Middle Class. Sociology 51(2):357-373.

KATZ, S., 2000: Busy Bodies: Activity, Aging, and the Management of Everyday Life. Journal of Aging Studies 14(2):135-152.

KLUMB, P. L. - BALTES, M. M., 1999: Time Use of Old and Very Old Berliners: Productive and Consumptive Activities as Functions of Resources. The Journals of Gerontology Series B: Psychological Sciences and Social Sciences 54B(5):271-278.

KUCHAŘOVÁ, V., 2002: Život ve stáří. Zpráva o výsledcích empirického šetření.

LAMONT, M. - MOLNÁR, V., 2002: The Study of Boundaries in the Social Sciences. Annual review of sociology 28(1):167-195.

LASLETT, P., 1989: A Fresh Map of Life: The Emergence of the Third Age. Weidenfeld and Nicolson.

LASSEN, A. J., 2014: Billiards, Rhytms, Collectives. Billiards at a Danish Activity Centre as a Culturally Specific Form of Active Ageing. Ethnologia Europaea. Journal of European Ethnology 44(1):57-74.

LASSEN, A. J. - MOREIRA, T., 2014: Unmaking Old Age: Political and Cognitive Formats of Active Ageing. Journal of Aging Studies 30:33-46.

LIN, N., 2017: Building a Network Theory of Social Capital. In: R. Dubos (ed.) Social Capital. Theory and Research. New York: Routledge.

LITWIN, H. - STOECKEL, K. J., 2014: Engagement and Social Capital as Elements of Active Ageing: An Analysis of Older Europeans. Sociologia e Politiche Sociali 17(3):931.

MARSILLAS, S. et al., 2017: Does Active Ageing Contribute to Life Satisfaction for Older People? Testing a New Model of Active Ageing. European Journal of Ageing. Získáno 8. červen 2017 (http://link.springer.com/10.1007/s10433-017-0413-8).

MENEC, V. H. - CHIPPERFIELD, J. G., 1997: Remaining Active in Later Life the Role of Locus of Control in Seniors' Leisure Activity Participation, Health, and Life Satisfaction. Journal of Aging and Health 9(1):105-125.

MOULAERT, T. - PARIS, M., 2013: Social Policy on Ageing: The Case of Active Ageing as a Theatrical Metaphor. International Journal of Social Science Studies 1(2):113-123.

PETROVÁ KAFKOVÁ, M., 2013: Šedivějící hodnoty? Aktivita jako dominantní způsob stárnutí. EDIS. Brno: Munipress.

PRINCIPI, A. et al., 2016: Retirement Plans and Active Ageing: Perspectives in three Countries. Ageing \& Society 38(1), 56-82. doi:10.1017/S0144686X16000866

RABUŠIC, L., 2004: Why Are They All So Eager to Retire? (On the Transition to Retirement in the Czech Republic). Sociologický časopis/Czech Sociological Review 40(3):319-342.

SCHERGER, S. - NAZROO, J. - HIGGS, P., 2011: Leisure Activities and Retirement: Do Structures of Inequality Change in Old Age? Ageing \& Society 31(01):146-172.

SILVERSTEIN, M. - PARKER, M. G., 2002: Leisure Activities and Quality of Life among the Oldest Old in Sweden. Research on Aging 24(5):528-547. 
SKUCHA, J. - BERNARD, M., 2000: Women's Work' and the Transition to Retirement. In: M. Bernard, J. Phillips, L. Machin, a V. H. Davies (eds.) Women Ageing: Changing Identities, Challenging Myths, editoval. Psychology Press. S. 23-40.

SOUKUP, P., 2006: Proč užívat hierarchické lineární modely? / Why Use Hierarchical Linear Models? Sociologický Časopis / Czech Sociological Review 42(5):987-1012.

SOUKUP, P. - RABUŠIC, L., 2007: Několik poznámek K jedné obsesi českých sociálních věd - statistické významnosti. Sociologický Časopis / Czech Sociological Review 43(2):379-395.

STALVEY, B. T. - OWSLEY, C. - SLOANE, M. E. - BALL, M., 1999: The Life Space Questionnaire: A measure of the extent of mobility of older adults. Journal of Applied Gerontology 18(4):460-478.

STENNER, P. - MCFARQUHAR, T. - BOWLING, A., 2011: Older People and 'active Ageing': Subjective Aspects of Ageing Actively. Journal of Health Psychology 16(3):467-477.

TINKER, A., 2014: Older People in Modern Society. Routledge.

TOWNSEND, J. - GODFREY, M. - DENBY, T., 2006: Heroines, Villains and Victims: Older People's Perceptions of Others. Ageing \& Society 26(06):883-900.

VENN, S. - ARBER, S., 2011: Day-Time Sleep and Active Ageing in Later Life. Ageing \& Society 31(02):197-216.

VERBRUGGE, L. M. - GRUBER-BALDINI, A. L. - FOZARD, J. L., 1996: Age Differences and Age Changes in Activities: Baltimore Longitudinal Study of Aging. The Journals of Gerontology Series B: Psychological Sciences and Social Sciences 51B(1):3041.

VIDOVIĆOVÁ, L., 2013: Představy o starobním důchodu a jeho časování - vliv legislativy, práce a rodiny. Fórum sociální politiky 7(2): 2-9.

VIDOVIĆOVÁ, L., 2005: To be Active or Not to be Active, that is the Question: The Preference Model of Activity in Advanced Age. Ageing International 30(4):343-362.

VIDOVIĆOVÁ, L., 2018: Vybrané rozdíly v kvalitě života českých seniorů ve městě a na venkově. Fórum sociální politiky 12(3):2-8.

VIDOVIĆOVÁ, L. - GALČANOVÁ, L. - PETROVÁ KAFKOVÁ, M. - SÝKOROVÁ, D., 2013: Stárí ve městě, město v životě seniorů. Studie. Praha, Brno: Sociologické nakladatelství, Masarykova univerzita.

VIDOVIĆOVÁ, L. - PETROVÁ KAFKOVÁ, M., 2012: Aktivity seniorů ve velkých městech: zdraví, prostor a subjektivní kvalita života. Sociologický časopis/Czech Sociological Review 48(5):939-963.

VIDOVIĆOVÁ, L. - PETROVÁ KAFKOVÁ, M., 2016: Index aktivního stárnutí (AAI) v regionální aplikaci. Demografie : Revue pro výzkum populačního vývoje 58(1):49-66.

WALKER, A., 2002: A Strategy for Active Ageing. International Social Security Review 55(1):121-139.

WEBER, M., 1930: The Protestant ethic and the spirit of capitalism.

WHO, 2002: Active Ageing: a Policy Framework.

WHO, 1998: Statement development by WHO Quality of Life Working Group. Geneva: World Health Organization.

WILSON, J., 2000: Volunteering. Annual Review of Sociology 26:215-240.

ZAIDI, A., 2015: Creating and Using the Evidence Base: The Case of the Active Ageing Index. Contemporary Social Science 10(2):148-159. 